\title{
Molecular characterization of African swine fever virus from outbreaks in Namibia in 2018
}

\author{
Umberto Molini $^{1,2}$ (D) | Borden Mushonga ${ }^{1}$ | Tirumala B. K. Settypalli ${ }^{3}$ | William G. Dundon ${ }^{3}$ | \\ Siegfried Khaiseb $^{2}$ | Mark Jago ${ }^{1}$ | Giovanni Cattoli ${ }^{3}$ | Charles E. Lamien ${ }^{3}$
}

${ }^{1}$ Faculty of Agriculture and Natural Resources, School of Veterinary Medicine, University of Namibia, Windhoek, Namibia

${ }^{2}$ Central Veterinary Laboratory, Windhoek, Namibia

${ }^{3}$ Animal Production and Health Laboratory, Department of Nuclear Sciences and Applications, Joint FAO/IAEA Division of Nuclear Techniques in Food and Agriculture, International Atomic Energy Agency, Vienna, Austria

\section{Correspondence}

Umberto Molini, Faculty of Agriculture and Natural Resources, School of Veterinary Medicine, University of Namibia, Windhoek, Neudamm Campus, Namibia. Email: u.molini76@gmail.com

\begin{abstract}
Five samples were collected from four suspected outbreaks of African swine fever in Namibia in 2018. Sequencing of the C-terminus of the B646L gene (p72 protein), the central hypervariable region (CVR) of the B602L gene, the E183L gene (p54 protein) and the CD2v (used to determine the serogroup) was performed on DNA isolated from the samples. Phylogenetic analyses of the B646L (p72) revealed that one of the samples belonged to genotype I while the remaining samples could not be assigned to any currently known genotype. In contrast, by using the $E 183 \mathrm{~L}$ gene three of the samples were shown to belong to genotype Id and only two were of unknown genotype. Based on the analysis of the partial CD2v amino acid sequences of four of the samples, one of the viruses clustered with serogroup 2 while the other three did not cluster within any of the eight known serogroups. Examination of the CVR identified three variants with 8,18 and 24 tetrameric tandem repeat sequences. This study indicates that at least three different genetically distinct ASFV are currently present in Namibia.
\end{abstract}

\section{KEYWORDS}

African swine fever, Namibia, outbreak, phylogenetic analysis, pigs

\section{1 | INTRODUCTION}

African swine fever (ASF) is a disease of domestic pigs caused by ASF virus, a DNA virus which is the sole member of the family Asfarviridae (Dixon et al., 2000). The virus can be transmitted either through a sylvatic cycle involving soft ticks and asymptomatically infected warthogs or by a domestic cycle involving soft ticks and domestic pigs (Dixon, Sun, \& Roberts, 2019). ASF causes serious economic losses and high mortality rates in domestic pigs when affected. The disease is of global concern given that ASFV has spread to countries outside of the African continent and has now been detected in Europe, Russia, China and Southeast Asia (Cwynar, Stojkov, \& Wlazlak, 2019; Gogin, Gerasimov, Malogolovkin, \& Kolbasov, 2013; Mur et al., 2016; Zhou et al., 2018). The disease is endemic in most African countries where pigs are bred. Every year in Namibia, ASF causes sporadic outbreaks throughout the country. There is currently no vaccine against ASF and the available control strategies in Namibia focus on strict compartmentalization (farm biosecurity) by separating domestic pigs from sylvatic hosts and 'stamping out' of pigs within infected farms (Penrith \& Vosloo, 2009). In recent years, several molecular epidemiological reports have characterized ASFVs circulating in African countries including Namibia (Quembo, Jori, Vosloo, \& Heath, 2018; Simulundu et al., 2018). These studies have provided valuable information on the transboundary movement of this virus but have also highlighted the continuing evolution and genotypic variability of ASFV in Africa (Luka et al., 2017; Mulumba-Mfumu et al., 2017; Wade et al., 2019).With this in mind, this study was undertaken to genetically characterize recent ASFVs involved in outbreaks in Namibia.

\section{2 | MATERIALS AND METHODS}

In 2018, four suspected outbreaks of ASF from four domestic farms (Farm A, Farm B, Farm C and Farm D) located in 3 different regions 
of Namibia (e.g. Khomas, Otjozondjupa and Omaheke) were reported to the state veterinary authorities. Tissue samples were collected from dead animals ( $n=5$ ) and sent to the Central Veterinary Laboratory (CVL), Windhoek, Namibia, for further disease investigation (Table 1). Farms A and B are located in the same district
(Windhoek), $33 \mathrm{~km}$ from each other. Farm C and Farm D are approximately $420 \mathrm{~km}$ distant from each other and approximately 250 and $600 \mathrm{~km}$ from Farm A and B, respectively (Figure 1). All of the farms reported $20 \%$ mortality among their pigs (Table 1). Prior to death some of the diseased pigs presented with peracute death

TAB LE 1 Samples analysed in this study

\begin{tabular}{|c|c|c|c|c|c|c|c|c|c|c|c|c|}
\hline Farm & $\begin{array}{l}\text { Sample } \\
\text { ID \# }\end{array}$ & $\begin{array}{l}\text { Sample } \\
\text { type }\end{array}$ & Location & Region & $\begin{array}{l}\text { Collection } \\
\text { date }\end{array}$ & $\begin{array}{l}\text { Pigs in } \\
\text { farm } \\
\text { (n) }\end{array}$ & $\begin{array}{l}\text { Age } \\
\text { affected } \\
\text { (years) }\end{array}$ & Breed & Clinical signs & $\begin{array}{l}\text { Interaction } \\
\text { with wildlife }\end{array}$ & Origin & Mortality \\
\hline A & 1025_1 & $\begin{array}{l}\text { Lymph } \\
\text { node }\end{array}$ & Windhoek & Khomas & $\begin{array}{c}24 / 02 / \\
2018\end{array}$ & 50 & $\begin{array}{l}\text { From } 1 \\
\text { to } 4\end{array}$ & $\begin{array}{l}\text { Landrace } \\
\text { hybrid }\end{array}$ & $\begin{array}{l}\text { Sternal recum- } \\
\text { bency, reluc- }\end{array}$ & Yes & Local & $18.0 \%$ \\
\hline A & 1028 & Spleen & & & $\begin{array}{c}14 / 03 / \\
2018\end{array}$ & & & & $\begin{array}{l}\text { tance to move, } \\
\text { inappetence, } \\
\text { gasping, exten- } \\
\text { sion of the neck, } \\
\text { sinusitis and } \\
\text { coughing }\end{array}$ & & & \\
\hline B & 2133 & Spleen & Windhoek & Khomas & $\begin{array}{c}02 / 05 / \\
2018\end{array}$ & 21 & $\begin{array}{c}\text { From } 2 \\
\text { to } 3\end{array}$ & $\begin{array}{l}\text { Landrace } \\
\text { hybrid }\end{array}$ & $\begin{array}{l}\text { Dead without } \\
\text { clinical signs }\end{array}$ & Yes & Local & $23.8 \%$ \\
\hline $\mathrm{D}$ & 4593 & $\begin{array}{l}\text { Lymph } \\
\text { node }\end{array}$ & Grootfontein & Otjozondjupa & $\begin{array}{c}29 / 08 / \\
2018\end{array}$ & 89 & $\begin{array}{l}\text { From } 1 \\
\text { to } 5\end{array}$ & $\begin{array}{l}\text { Landrace } \\
\text { hybrid }\end{array}$ & $\begin{array}{l}\text { Sternal re- } \\
\text { cumbency, } \\
\text { weakness, } \\
\text { inappetence }\end{array}$ & No & Local & $23.6 \%$ \\
\hline C & 5538 & Spleen & Gobabis & Omaheke & $\begin{array}{c}13 / 10 / \\
2018\end{array}$ & 40 & $\begin{array}{l}\text { From } 2 \\
\text { to } 4\end{array}$ & $\begin{array}{l}\text { Landrace } \\
\text { hybrid }\end{array}$ & $\begin{array}{l}\text { Sternal recum- } \\
\text { bency, weak- } \\
\text { ness, reluctance } \\
\text { to move }\end{array}$ & No & Local & $17.5 \%$ \\
\hline
\end{tabular}

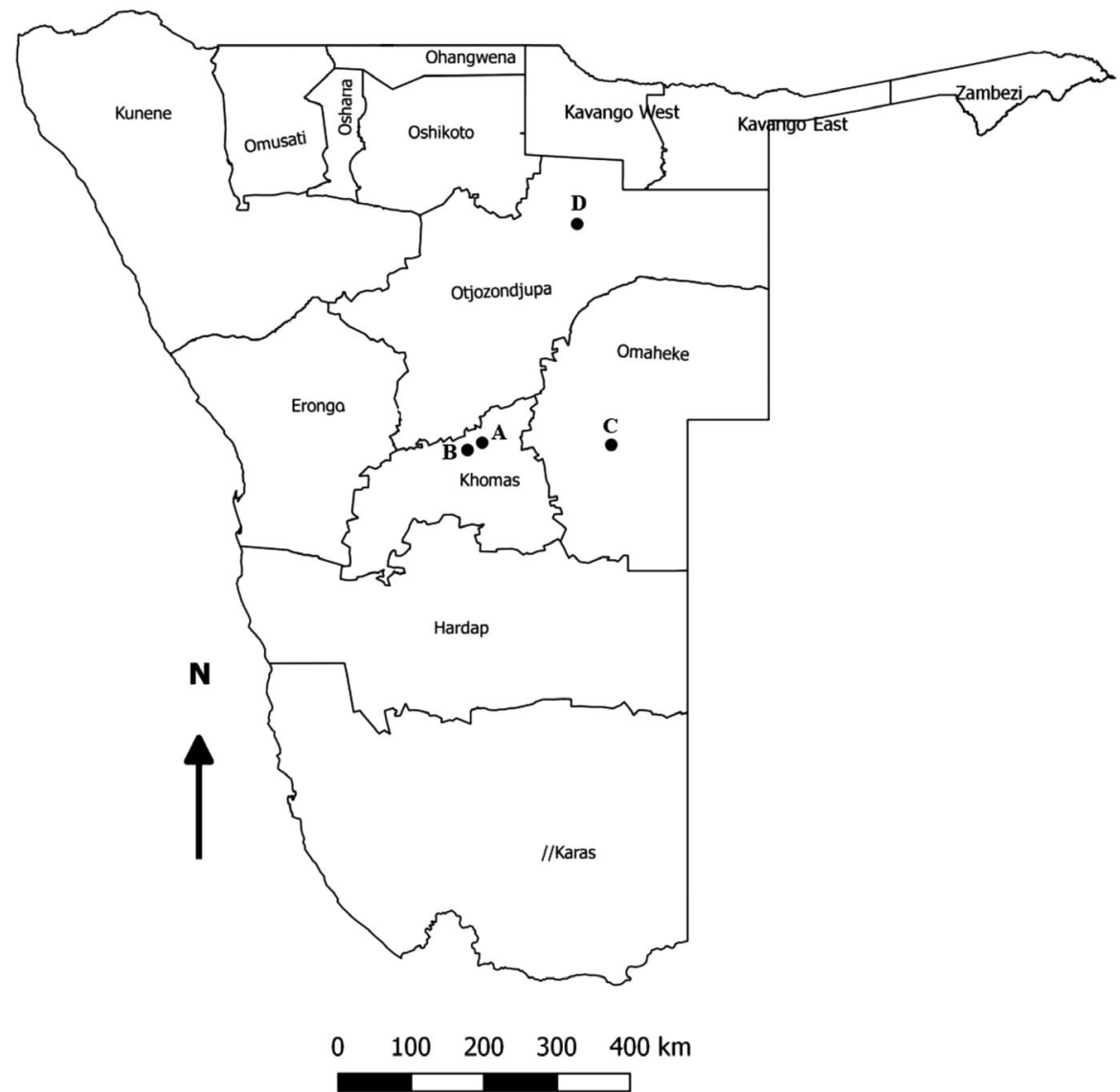

FIGURE 1 Geographic distribution of African swine fever outbreaks in Namibia in 2018 
while others presented with sternal recumbency, weakness, reluctance to move, hyperaemia of the skin (including the scrotum of the boar) inappetence, difficulties which included gasping, extension of the neck, sinusitis and coughing. Post-mortem examination revealed severe laryngotracheitis and the presence of blood and yellow exudates in the trachea; large patches of hyperaemia of the skin, large amounts of non-clotting blood in the peritoneal and pleural cavities, massive haemorrhage of the lymph nodes, massive congestion of the carcasses, splenomegaly, bilateral red hepatization of the lungs, haemorrhagic frothy airways, tracheal congestion, hepatomegaly, enlarged and congested kidneys, ecchymotic haemorrhages of the heart, and very enlarged and congested bladder with reddish-brown

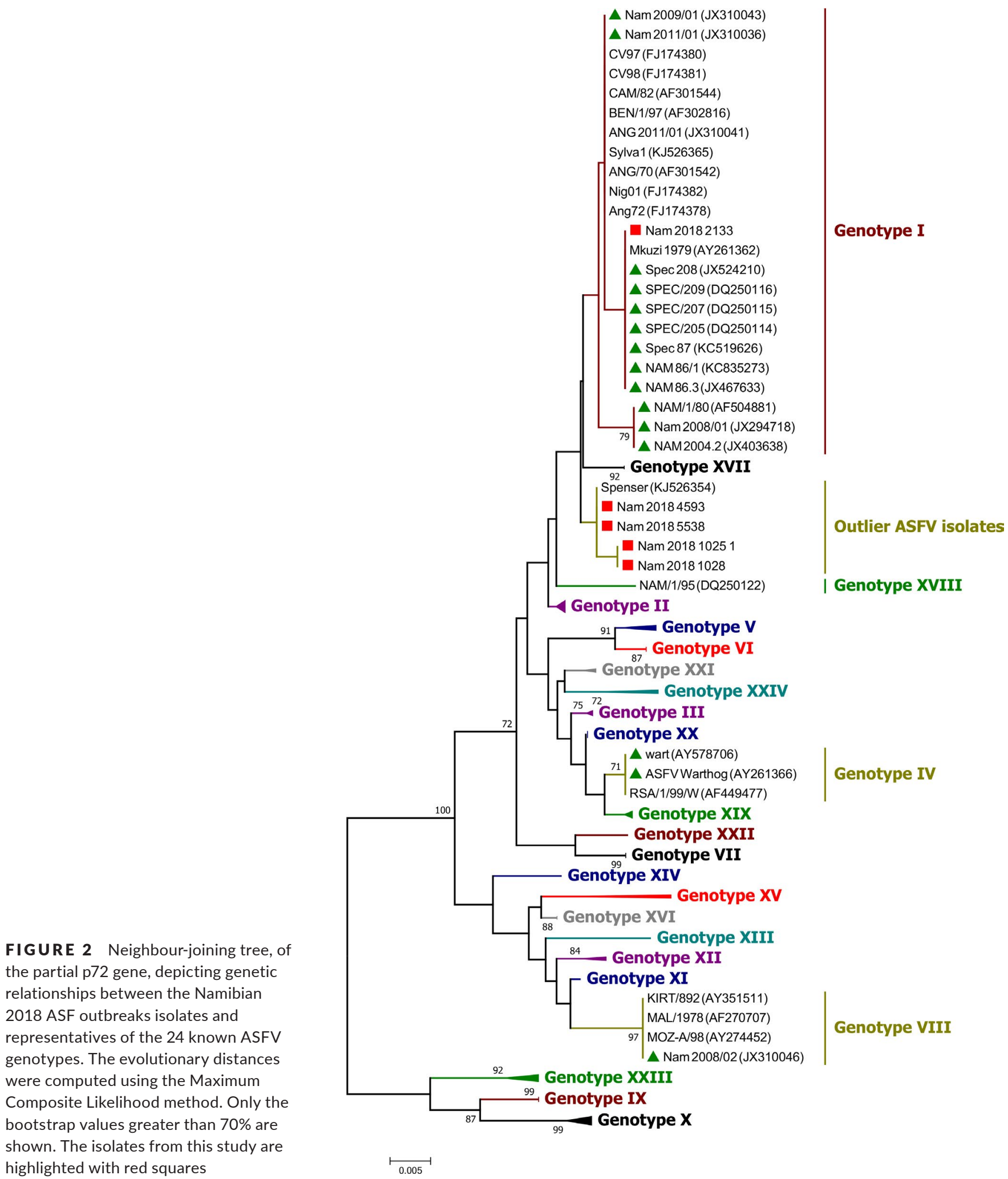


urine. Total genomic DNA was extracted from the samples using a Maxwell ${ }^{\circledR} 16$ Tissue DNA Purification Kit (Promega) with an elution volume of $300 \mu \mathrm{l}$ following the manufacturer's instructions. For ASFV specific DNA detection in the total nucleic acid extract, a method adapted from King et al., 2003 was used. For molecular characterization, the nucleic acid of the samples that tested positive for ASF were further amplified using three different sets of primers: p72-U (forward): 5'- GGCACAAGTTCGGACATGT - 3' and p72-D (reverse): 5'- GTACTGTAACGCAGCACAG- 3, targeting the C-terminal region of the $B 646 \mathrm{~L}$ gene encoding the p72 protein (Bastos et al., 2003), P54F-5'-GCCTGCGGATTCTGAAGATA-3' and P54R- 5' AGGACGCAATTGCTTAAACG-3' targeting the full length E183L (p54) gene encoding the p54 protein (Mulumba-Mfumu et al., 2017) and ORF9RLW_F-5'-AATGCGCTCAGGATCTGTTAAATCGG-3' andORF9 RLW_R-5'-TCTTCATGCTCAAAGTGCGTATACCT-3' targeting the central variable region (CVR) of the B602L gene (Irusta et al., 1996). To determine the serogroups of the isolates, the partial CD2v gene (Malogolovkin, Burmakina, Tulman, et al., 2015) was amplified and sequenced using two sets of primers ga3611for- 5'-TATAATATAACAAATAATTGTAG-3', ga4220rev-5'-AG GGACGCATGTAGTAAATAG-3', ga4124f-5'-CTGAATCTAATGAAGA AGA-3' and ga4698r-5'-AAGTCTTTGTAGGTTTTTCGTTCA-3' to generate two overlapping fragments using high-fidelity PCR kits
(Q5 High-Fidelity 2X Master Mix; Neb Inc) and $500 \mathrm{nM}$ primers in a $25 \mu \mathrm{l}$ reaction and the following thermal profile: initial denaturation at $95^{\circ} \mathrm{C}$ for $5 \mathrm{~min}$ and then 40 cycles of denaturation at $95^{\circ} \mathrm{C}$ for $45 \mathrm{~s}$, annealing at $52^{\circ} \mathrm{C}$ for $45 \mathrm{~s}$ and elongation at $72^{\circ} \mathrm{C}$ for $90 \mathrm{~s}$, followed by a final elongation at $72^{\circ} \mathrm{C}$ for $5 \mathrm{~min}$. All of the samples investigated were positive for ASFV by real-time PCR. For the molecular characterization of the samples, all gene fragments were successfully amplified except for the CD2v fragment of sample Nam_2018_1028. Amplicons were purified using the Wizard ${ }^{\circledR}$ SV Gel and PCR CleanUp System (Promega) and sent for sequencing at LGC genomics (Berlin, Germany). All sequences generated in this study have been submitted to GenBank under accession numbers (MK686046 to MK686065). The partial B646L (p72) and the full E183L (p54) gene sequences were used to determine the genotype of the viruses by phylogenetic analysis, while the $C D 2 v$ sequence fragment was analysed to determine the serogroup. All sequence alignments and phylogenetic analyses were performed using MEGA 7. A neighbourjoining (NJ) tree for the B646L (p72) nucleotide sequences was constructed using the Maximum Composite Likelihood (MCL) method. A neighbour-joining (NJ) tree was produced for the $\mathrm{p} 54$ nucleotides sequences using the Kimura 2-parameter method. For the CD2v gene, a maximum-likelihood (ML) tree of the partial amino acid sequences was constructed applying the predetermined CpREV + G model.

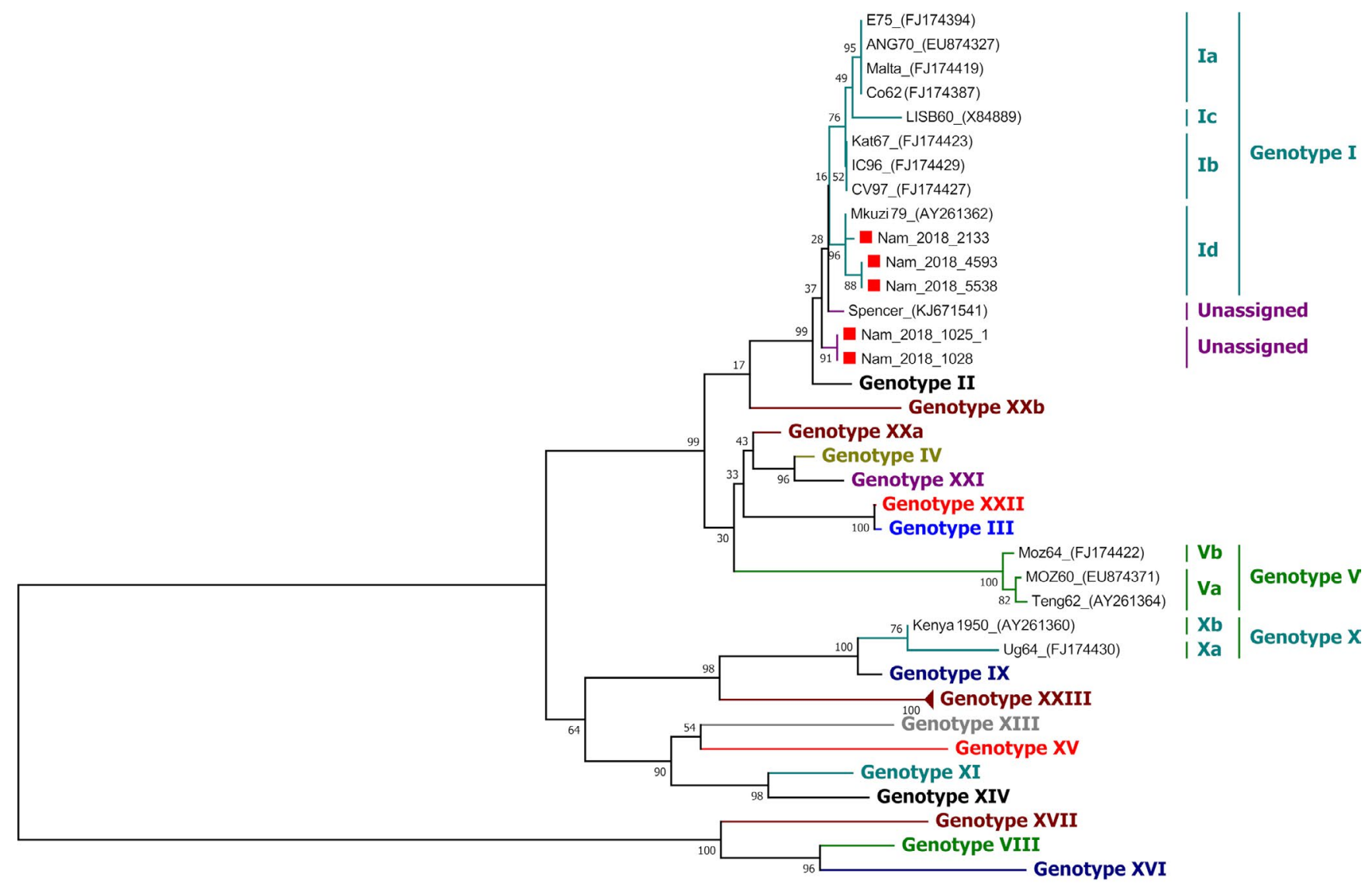

0.05

FIGURE 3 Neighbour-joining tree, based on the full p54 gene, depicting genetic relationships between the Namibian 2018 ASF outbreaks isolates and representatives of 18 of the 24 known ASFV genotypes. The evolutionary distances were computed using the Kimura 2-parameter method. Only the bootstrap values greater than $70 \%$ are shown. The isolates from this study are highlighted with red squares 


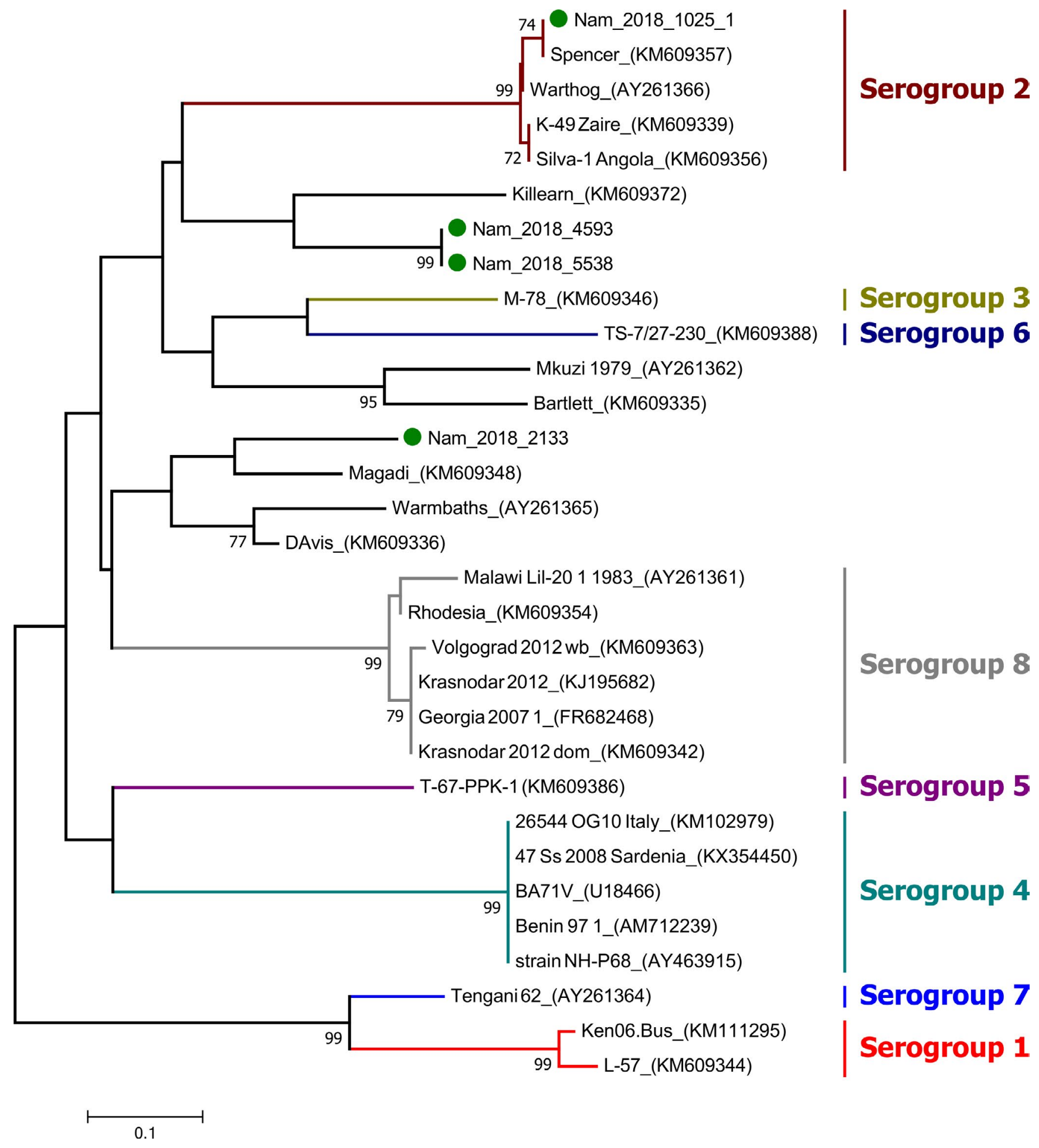

FIGURE 4 Maximum-likelihood tree based on the partial amino acid sequence of the CD2v protein. The tree shows the relationship between the Namibian 2018 ASF outbreaks isolates (highlighted with green diamonds), and the representatives of the eight known ASFV serogroups as well as ASFVs clustering outside the eight established serogroups. The General Reversible Chloroplast model Gamma distribution was used. Only the bootstrap values greater than $70 \%$ are shown

\section{3 | RESULTS AND DISCUSSION}

For the p72 analysis (Figure 2) sample Nam_2018_2133 (Farm B) clearly clustered with genotype I viruses together with a few historical samples from Namibia. Genotype I viruses have been previously identified in Namibia and neighbouring Angola, Zambia and South Africa, in other African countries (e.g. Nigeria, Cameroon and Ivory Coast) in Europe and Latina America (Bastos et al., 2003; Boshoff, Bastos, Gerber, \& Vosloo, 2007). The p72 sequences of samples Nam_2018_1025_1 and Nam_2018_1028 


\begin{tabular}{|llc|}
\hline Isolate name & CVR & Number of repeats \\
\hline Nam_2018_4593 & BNAAAFBTDBNAFNBTFNBNAAAF & 24 \\
\hline Nam_2018_5538 & BNAAAFBTDBNAFNBTFNBNAAAF & 24 \\
\hline Nam_2018_1025_1 & BNAAHAAF & 8 \\
\hline Nam_2018_1028 & BNAAHAAF & 8 \\
\hline Nam_2018_2133 & BNAFNBNAAAFNBNAAAF & 18 \\
\hline
\end{tabular}

TAB LE 2 CVR profiles of Namibian viruses from Farm A were identical to each other as were the samples from Farm C and D (e.g. Nam_2018_4593 and Nam_2018_5538). These four sequences showed the highest identity ( 99.75 to $100 \%$ ) with the South African 'Spenser' isolated (KJ526354) from 1985 that is the only member identified to date of an unnamed genotype (Malogolovkin, Burmakina, Titov, et al., 2015). This strongly indicates a shared origin of the 'Spenser' virus and the four Namibian viruses. On the p54 phylogenetic tree (Figure 3), Nam_2018_4593 and Nam_2018_5538 cluster with Nam_2018_2133 in subgenotype Id while Nam_2018_1025, while Nam_2018_1028 did not cluster within any of the known genotypes. Analysis of the p54 gene is known to give finer levels of discrimination (Giammarioli et al., 2011) within each genotype. Indeed, Nam_2018_4593 and Nam_2018_5538 could not be assigned to any genotype using the p72 gene fragment, while phylogenetic analysis of the p54 gene fragment located them within genotype I. This highlights the limitation of the current genotype classification of ASFVs based on the p72 gene. For the serogroup determination using the sequence of the CD2v, only sample Nam_2018_1025_1 could be assigned a serogroup (e.g. serogroup 2), similar to isolate Spencer from South Africa (Figure 4). Sample Nam_2018_1028 was not included in this comparison as the sequence of the entire fragment was not obtained. The other three remaining samples did not cluster within any of the currently established serogroups. As serogroup determination is based on a viral neutralization test and the current correlation of the CD2v sequences to serogroup is based on a limited number of isolates and so, it is not surprising that many isolates like NAM_2018_2133, Nam_2018_4593 and Nam_2018_5538 did not cluster within any of the eight established serogroups. To analyse the CVR profile of the Namibian ASFVs, the amino acid tetramers of the $\mathrm{B} 602 \mathrm{~L}$ gene were matched with previously reported codes (Achenbach et al., 2017; Gallardo et al., 2009). The examination of the CVR (Table 2) identified three variants with 8 tetrameric tandem repeat sequences for samples Nam_2018_1025_1 and Nam_2018_1028, 18 for sample Nam_2018_2133 and 24, for samples Nam_2018_4593 and Nam_2018_5538. A study of ASFVs in southern Africa between 1973 and 1999 was carried out by Boshoff et al. (2007). The authors included five viruses identified in Namibia in 1980, 1989 and 1995 (Bastos et al., 2003). Four of these viruses belonged to genotype I according to analysis of the p72 and one to genotype XVIII. In this study, it can be seen that ten ASFV isolates collected in Namibia between 1980 and 2011 are from genotype I, one is from genotype VIII and two warthog isolates are from genotype IV (Figure 2). The genotype I and XVIII viruses characterized by Boshoff et al. (2007) have CVR lengths of 11 tetramers (44 amino acids) and 21 tetramers (84 amino acids) respectively, and the Namibian warthog isolate (AY261366) has a CVR length of 15 tetramers ( 60 amino acids), different from those of this study. Samples taken from Farm C and D were identical to each other in all of the analyses undertaken indicating that there was an epidemiological link between the outbreaks in these two farms. In contrast, samples from Farms $A$ and $B$ were unique to the farm and so outbreaks were not epidemiologically related. Interestingly, each farm reported that all of their pigs are born and raised within the respective premises and that there is no exchange of material, personnel or animals between the farms. However, each farm has reported the presence of wild warthogs in their vicinity which suggests that the sylvatic cycle may have played a part in the transmission of ASFV to these farms. In conclusion, the multi-locus genetic characterization of the AFSVs from 4 separate outbreak has identified three genetically distinct viruses in Namibia, in 2018. Whether there are other ASFV genotypes circulating in the country will require further sample collection, monitoring and surveillance. In the meantime, this study has generated comparative data for those interested in the presence and movement of ASFV in southern Africa.

\section{ACKNOWLEDGEMENTS}

We are grateful for the funding provided by the International Atomic Energy Agency (IAEA) project 'Improvement of Veterinary Laboratory Capacities in Sub-Saharan African Countries' and for the sequencing services provided from the Animal Production and Health Sub-programme of the Joint FAO/IAEA Division in Vienna, Austria.

\section{ETHICAL APPROVAL}

Ethical clearance is not applicable.

\section{CONFLICT OF INTEREST}

The authors declare no conflicts of interest.

\section{ORCID}

Umberto Molini iD https://orcid.org/0000-0003-4146-4015 


\section{REFERENCES}

Achenbach, J. E., Gallardo, C., Nieto-Pelegrín, E., Rivera-Arroyo, B., Degefa-Negi, T., Arias, M., ... Sánchez-Vizcaíno, J. M. (2017). Identification of a new genotype of African Swine Fever Virus in Domestic Pigs from Ethiopia. Transboundary and Emerging Diseases, 64(5), 1393-1404. https://doi.org/10.1111/tbed.12511

Bastos, A. D., Penrith, M. L., Crucière, C., Edrich, J. L., Hutchings, G., Roger, F., ... Thomson, G. (2003). Genotyping field strains of African swine fever virus by partial p72 gene characterisation. Archives of Virology, 148(4), 693-706. https://doi.org/10.1007/s00705-002-0946-8

Boshoff, C. I., Bastos, A. D., Gerber, L. J., \& Vosloo, W. (2007). Genetic characterisation of African swine fever viruses from outbreaks in southern Africa (1973-1999). Veterinary Microbiology, 121(1-2), $45-$ 55. https://doi.org/10.1016/j.vetmic.2006.11.007

Cwynar, P., Stojkov, J., \& Wlazlak, K. (2019). African Swine Fever Status in Europe. Viruses, 30, 11. pii: E310.

Dixon, L. K., Costa, J. V., Escribano, J. M., Rock, D. L., Viñuela, E., \& Wilkinson, P. J. (2000). Family Asfarviridae. In M. H. V. Van Regenmortel, C. M. Fauquet, D. H. L. Bishop, E. B. Carestens, M. K. Estes, S. M. Lemon, J. Maniloff, M. A. Mayo, D. J. McGeoch, C. R. Pringle, R. B. F. A. Wickner, C. M. Murphy, D. H. L. Fauquet, S. A. Bishop, A. W. Ghabrial, G. P. Jarvis, \& M. D. Martelli (Eds.), Virus Taxonomy: Seventh Report of the International Committee on Taxonomy of Viruses (pp. 159-165). San Diego: Summers Academic Press.

Dixon, L. K., Sun, H., \& Roberts, H. (2019). African swine fever. Antiviral Research, 165, 34-41. https://doi.org/10.1016/j.antiv iral.2019.02.018

Gallardo, C., Mwaengo, D. M., Macharia, J. M., Arias, M., Taracha, E. A., Soler, A., ... Bishop, R. P. (2009). Enhanced discrimination of African swine fever virus isolates through nucleotide sequencing of the $\mathrm{p} 54$, p72, and pB602L (CVR) genes. Virus Genes, 38(1), 85-95. https://doi. org/10.1007/s11262-008-0293-2

Giammarioli, M., Gallardo, C., Oggiano, A., Iscaro, C., Nieto, R., Pellegrini, C., ... De Mia, G. M. (2011). Genetic characterisation of African swine fever viruses from recent and historical outbreaks in Sardinia (1978-2009). Virus Genes, 42(3), 377-387. https://doi.org/10.1007/ s11262-011-0587-7

Gogin, A., Gerasimov, V., Malogolovkin, A., \& Kolbasov, D. (2013). African swine fever in the North Caucasus region and the Russian Federation in years 2007-2012. Virus Research, 173(1), 198-203. https://doi. org/10.1016/j.virusres.2012.12.007

Irusta, P. M., Borca, M. V., Kutish, G. F., Lu, Z., Caler, E., Carrillo, C., \& Rock, D. L. (1996). Amino acid tandem repeats within a late viral gene define the central variable region of African swine fever virus. Virology, 220(1), 20-27. https://doi.org/10.1006/viro.1996.0281

King, D. P., Reid, S. M., Hutchings, G. H., Grierson, S. S., Wilkinson, P. J., Dixon, L. K., ... Drew, T. W. (2003). Development of a TaqMan PCR assay with internal amplification control for the detection of African swine fever virus. Journal of Virological Methods, 107(1), 53-61. https ://doi.org/10.1016/S0166-0934(02)00189-1

Luka, P. D., Achenbach, J. E., Mwiine, F. N., Lamien, C. E., Shamaki, D., Unger, H., \& Erume, J. (2017). Genetic characterization of circulating African swine fever viruses in Nigeria (2007-2015). Transboundary and Emerging Diseases, 64(5), 1598-1609. https://doi.org/10.1111/ tbed.12553

Malogolovkin, A., Burmakina, G., Titov, I., Sereda, A., Gogin, A., Baryshnikova, E., \& Kolbasov, D. (2015). Comparative analysis of African swine fever virus genotypes and serogroups. Emerging Infectious Diseases, 21(2), 312-315. https://doi.org/10.3201/eid2102.140649

Malogolovkin, A., Burmakina, G., Tulman, E. R., Delhon, G., Diel, D. G., Salnikov, N., ... Rock, D. L. (2015). African swine fever virus CD2v and C-type lectin gene loci mediate serological specificity. The Journal of General Virology, 96(4), 866-873. https://doi.org/10.1099/ jgv.0.000024

Mulumba-Mfumu, L. K., Achenbach, J. E., Mauldin, M. R., Dixon, L. K., Tshilenge, C. G., Thiry, E., ... Diallo, A. (2017). Genetic Assessment of African Swine Fever Isolates Involved in Outbreaks in the Democratic Republic of Congo between 2005 and 2012 Reveals Co-Circulation of p72 Genotypes I, IX and XIV, Including 19 Variants. Viruses, 9(2). 31. https://doi.org/10.3390/v9020031

Mur, L., Atzeni, M., Martínez-López, B., Feliziani, F., Rolesu, S., \& Sanchez-Vizcaino, J. M. (2016). Thirty-five-year presence of African swine fever in Sardinia: History, evolution and risk factors for disease maintenance. Transboundary and Emerging Diseases, 63(2), 165-177. https://doi.org/10.1111/tbed.12264

Penrith, M. L., \& Vosloo, W. (2009). Review of African swine fever: Transmission, spread and control. Journal of South Africa Veterinary Association, 80(2), 58-62.

Quembo, C. J., Jori, F., Vosloo, W., \& Heath, L. (2018). Genetic characterization of African swine fever virus isolates from soft ticks at the wildlife/domestic interface in Mozambique and identification of a novel genotype. Transboundary and Emerging Diseases, 65(2), 420-431. https://doi.org/10.1111/tbed.12700

Simulundu, E., Chambaro, H. M., Sinkala, Y., Kajihara, M., Ogawa, H., Mori, A., ... Mweene, A. S. (2018). Co-circulation of multiple genotypes of African swine fever viruses among domestic pigs in Zambia (2013-2015). Transboundary and Emerging Diseases, 65(1), 114-122. https://doi.org/10.1111/tbed.12635

Wade, A., Achenbach, J. E., Gallardo, C., Settypalli, T. B. K., Souley, A., Djonwe, G., ... Lamien, C. E. (2019). Genetic characterization of African swine fever virus in Cameroon, 2010-2018. Journal of Microbiology, 57(4), 316-324. https://doi.org/10.1007/ s12275-019-8457-4

Zhou, X., Li, N., Luo, Y., Liu, Y., Miao, F., Chen, T., ... Hu, R. (2018). Emergence of African swine fever in China, 2018. Transboundary and Emerging Diseases, 65(6), 1482-1484. https://doi.org/10.1111/ tbed.12989

How to cite this article: Molini U, Mushonga B, Settypalli TBK, et al. Molecular characterization of African swine fever virus from outbreaks in Namibia in 2018. Transbound Emerg Dis. 2019;00:1-7. https://doi.org/10.1111/ tbed.13399 